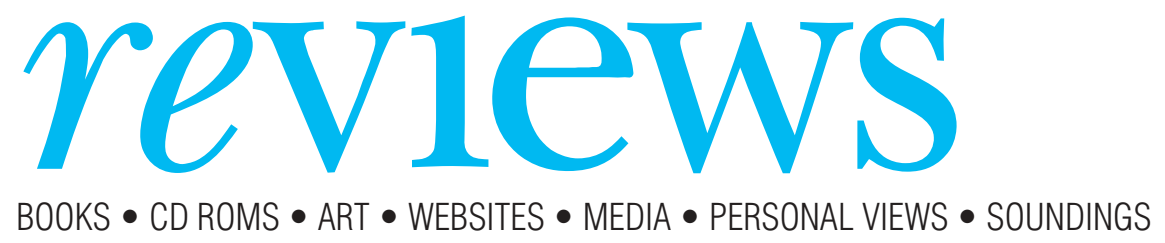

\author{
Nerve Endings: The \\ Discovery of the Synapse \\ Richard Rapport
}

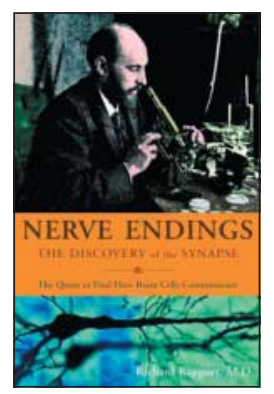

W W Norton, £15.99/\$23.95 pp 224

ISBN 0393060195

www.wwnorton.com

Rating: $\star \star \star \star$ 斿

$\mathrm{T}$ he Spanish histologist Santiago Ramón y Cajal (1852-1934) wrote in his memoir: "Really, the garden of neurology offers the researcher captivating spectacles and incomparable artistic emotions. My aesthetic instincts find there full satisfaction. Like the entomologist catching beautiful butterflies, my attention pursued in the garden of gray matter, the delicately and gracefully shaped cells, the mysterious butterflies whose wing beats might some day reveal the secret of mental life." Richard Rapport, a neurosurgeon from Seattle, found a copy of this book on a dusty shelf of a secondhand book shop, and it inspired him to tell a story aimed at a general audience about the life and work of this "constant gardener."

The son of a doctor's assistant in a remote Spanish village, Cajal had been interested in painting and photography from childhood and preferred Jules Verne's novels to academic routine. In 1877 he was appointed assistant professor of anatomy at the University of Zaragoza and managed to buy a microscope of his own, for an enormous sum, and a microtome. Cajal's laboratory occupied a table in the kitchen of his house.

By this time Camillo Golgi in Italy had already discovered the method for silver nitrate staining to expose neurones by their darkened outlines. Cajal further developed not only Golgi's staining technique but also his theory of neural conduction. While Golgi was convinced of the existence of a reticular network that connected nerve cells, Cajal argued that the nervous system is composed of units, without continuity of substance between cells. Rapport compares Golgi's view of the nervous system to "a kind of ant colony,

Items reviewed are rated on a 4 star scale (4=excellent) made up of passages that routed information through an entirely connected labyrinth ... Where Golgi had seen the tunnels of an anthill, Cajal saw the ants." The terms we now use were coined later by other researchers"dendrite" in 1889, "neurone" in 1891, "axon" in 1896, and "synapse" in 1897.

Rapport notes that "scientific theories are little more than intellectual models devised to define a strategy for collecting data about the physical world." By the early 1890s the neurone theory had come to dominate among neurohistologists. According to this theory an electrical impulse is transmitted only in one direction: from the dendrite to the cell body and then further along the axon. Rapport notes, "It wasn't so much that the reticular theory had been wrong as that it was no longer a useful way to examine the problem."

"If one wanted to explain the influence of Cajal's work on neurological science today, one would have to write the history of neurology in the last ninety years," wrote Fernando Reinon-Suarez in 1981. Rapport has attempted it in one 14 page chapter. Electron microscopy permits us to visualise the synaptic cleft and to measure its width (2-3 nanometres). The number of contacts of a neurone might vary from 1000 to 80000 . Biochemistry has explained the transmission of electrical current (action potential) across the synapses. However, there are synapses called gap junctions where the cell membranes are so close to each other that electrical signals are transmitted directly from presynaptic to postsynaptic structures without any chemical involvement. Furthermore, some molecules travel from one cell to another through gap junctions without entering into extracellular space. So, it turns out that Golgi was also right.

Nevertheless, Rapport makes the strange claim that Cajal's identification of the gap "made the neuron theory law and eventually allowed ... surgery of the brain." The specialty of neurosurgery emerged with the concepts of intracranial pressure and cerebral localisation, which had nothing to do with neurone theory. Rapport's claim reminded me of discussions I had about a decade ago with Harold Hillman from the Unity Laboratory of Applied Neurobiology at the University of Surrey, during my fellowship at the Wellcome Institute for the History of Medicine in London. Dr Hillman summarised his concerns about the limitations in our understanding of neurones in a recent paper (Medical Hypotheses 2003;61:190-3). What evidence is there that

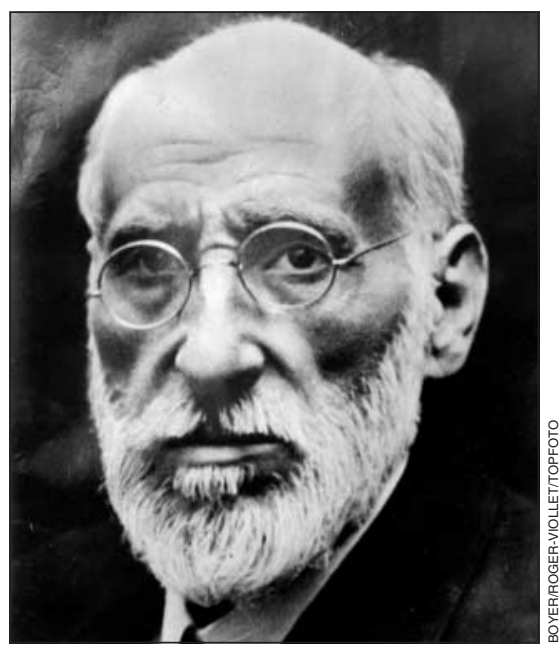

Cajal: passionate

learning, memory, self consciousness, or the mind affect synapses? Does the chemical theory of transmission contain unproved and unprovable sub-hypotheses? Why are synapses regarded as necessary for the transmission of information, when electric conduction conveys information without crossing synapses? These are only three of 27 questions on neurobiology in Hillmann's article. Rapport's book addresses none of them.

Cajal and Golgi shared the 1906 Nobel prize for medicine. Rapport concludes that "for both of them in the end, who was right depended, at least in part, on a matter of intuition and manner ... Looking down similar microscopes at the same tissues, they each saw a different nervous system." Rapport explains the difference: "Whereas Cajal saw the world through the eyes of a passionate, liberal south Mediterranean, Golgi saw the same world with the colder eye of a conservative northerner." However, such a geopolitical explanation is unconvincing.

In its clear and metaphorical language Nerve Endings echoes the passionate style of Cajal's memoirs. It has many other advantages: a historical context, carefully selected illustrations, a glossary, and an outline of basic neurophysiological processes (action and resting potentials, depolarisation, electrical gradients, and so on). It also has a bibliography-often missing in books at a general readership. It surely deserves a paperback edition.

Boleslav L Lichterman Centre for the History of Medicine, Russian Academy of Medical Sciences, Moscow

licht@aha.ru 
Using Terri: The Religious Right's Conspiracy to Take Away Our Rights

Jon B Eisenberg

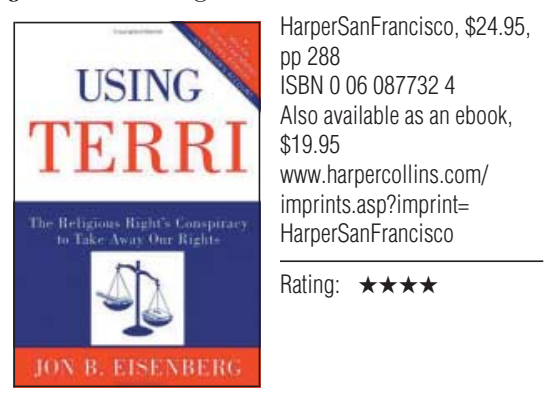

$\mathrm{T}$ he case of Terri Schiavo, a brain dead Florida woman at the centre of a family battle over whether she should be kept alive or be allowed to die, is one that divided America last year, pitching right against left and religious groups against secular sentiment (BMJ 2005;330:687). Terri, who died on 31 March 2005 , had been on a life support machine for 15 years after a cardiac arrest. She was in a persistent vegetative state and had received artificial nutrition and hydration via a percutaneous endoscopic gastrostomy against her previous wish to her husband, Michael, not to be kept alive "on anything artificial." An autopsy showed massive cerebral atrophy.

Terri's parents, however, fiercely opposed her husband's decision to let her die; Florida governor Jeb Bush was a strong supporter of their case. Both camps took their case through the courts in what became one of the most high profile life and death struggles in US media history.

This book, by a lawyer who joined Michael Schiavo's legal team in March 2005, argues that there is a vast right-wing conspiracy "to change America into a theocracy where the [US] Constitution is subservient to the Bible and religious fundamentalists across the Judeo-Christian spectrum would intrude on our lives from conception to death by taking away our rights of personal autonomy." In a nutshell, according to Howard Ahmanson Jr, "one of the ultrarich funders" of the religious right, whom Eisenberg quotes, "My purpose is total integration of biblical law into our lives" ( $p$ 95).

Whereas most bioethicists, says Eisenberg, uphold the concept of personal choice over artificial nutrition and hydration in an advanced directive or living will, the religious right opposes it. Moreover, the religious right viewed the emotive case of Terry
Schiavo as a crucial episode in the battle for hearts and minds over a whole range of personal autonomy issues from gay rights to abortion, and, Eisenberg claims, had its big guns lined up in support of Terri's parents, $\mathrm{Mr}$ and Mrs Schindler.

Eisenberg provides well researched evidence of this, identifying - in addition to Jeb Bush-seven foundations and 14 think-tanks in the high command behind the Schindlers, as well as 18 "foot soldiers" (activists, lawyers, and politicians). He also exposes the efforts in Congress to breach the separation of powers in the US Constitution, and to over-ride the judiciary at the state level.

Using Terri takes the reader through a maze of legal manoeuvres crafted mostly by lawyers for the Schindlers, waging a last-ditch fight in the courts, the Florida legislature, and Governor Jeb Bush's office, and even going as far as President George W Bush and the US Congress. But for all its efforts, in the end the religious right's Terri crusade was unsuccessful. Two polls by CBS News and ABC News in March 2005 showed $70 \%$ and $82 \%$ of Americans felt that Congress was wrong to intervene in the Schiavo case.

Fred Charatan retired geriatric physician, Boynton Beach, Florida, USA

charatanf@bellsouth.net

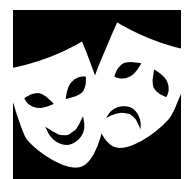

\section{Gladiator Games}

A co-production by Sheffield Theatres and Theatre Royal Stratford East

Dramatised by Tanika Gupta

Directed by Charlotte Westenra

Theatre Royal Stratford East, London, 2 to 25 February 2006

\section{Rating: $\star \star \star \star$}

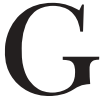
ladiator Games dramatises the events surrounding the death of an Asian teenager, Zahid Mubarek, in UK custody. He was remanded on 17 January 2000 for stealing razor blades worth $£ 6$ and for interfering with a motor vehicle. He was taken to Feltham Young Offenders' Institution in west London and eventually sentenced to three months.

His killer, Robert Stewart, received his first conviction at the age of 13 and was well known within the Prison Service as a violent, dangerous, and racist psychopath. By the age of 19, he had had 18 separate convictions for 71 offences. Despite this, on 8 February 2000, he was put in the same cell as Mubarek, whom he attacked on the night before Zahid's planned release. A week later, Zahid died in hospital.

The Mubarek family called for an independent public inquiry, but this went unheeded. Stewart was found guilty of murder at Kingston Crown Court on 1 November 2000. The Commission for Racial Equality launched an internal investigation and reported on institutional racism within the prison system. The Mubarek family continued to challenge the home secretary's decision not to hold a public inquiry, and their case went as far as the House of Lords until the inquiry opened in May 2004. It is due to publish its report in April 2006.

Gladiator Games, based on interviews and accounts given to the Feltham inquiry by various witnesses, also portrays the work of two psychiatrists involved in the case. Professor John Gunn told the inquiry that there was much evidence to suggest that Robert Stewart was seriously mentally disordered. He had been seen 29 times by medical healthcare staff since 1995 but never by a psychiatrist. Professor Gunn said that if there had been an appropriate and detailed psychiatric assessment, it would have been extremely unlikely that he would have been able to share a cell with an Asian man. Another psychiatrist saw Stewart on behalf of the defence solicitors and concluded that he had a severe personality disorder and was a psychopath.

The play raises disturbing issues for the medical profession in general, which can no longer sweep prison health care under the

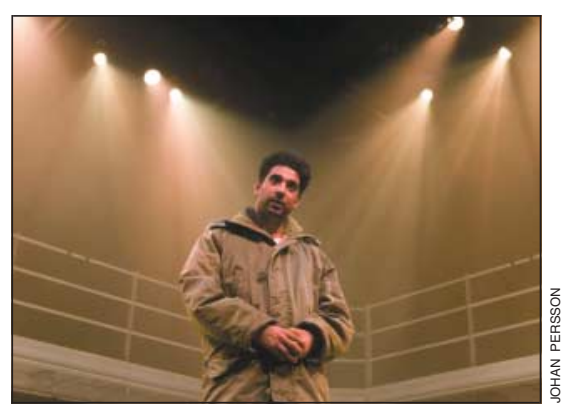

The play raises disturbing issues for the medical profession

carpet now that primary care trusts have officially taken over responsibility for it. The medical assessments in this case did not identify the need for a psychiatric evaluation, an omission that eventually proved fatal.

One could argue that some of the resources that the government has invested in setting up separate facilities for the treatment of dangerous and severely personality disordered (DSPD) prisoners and patients could be better spent offering training to prison medical staff in diagnosing and risk-assessing personality disorder. This would offer better public protection and also help the government to gain some muchneeded support from doctors for its controversial DSPD project.

Piyal Sen consultant forensic psychiatrist, Priory/Blenheim Secure Services, Chadwick Lodge, Milton Keynes 


\section{How can we improve the rate of autopsies among Muslims?}

\begin{abstract}
A mong Muslim people in Britain the uptake of autopsies in general, and perinatal and paediatric autopsies in particular, is low. Family members may decline consent for an autopsy for several reasons: they believe that Islam doesn't allow autopsy; they see no need for an autopsy because of their belief that death is God's will; advances in medical knowledge mean that everything is already known about the case and hence an autopsy isn't necessary; they fear that the body will be desecrated; and they worry that an autopsy will prevent the body from being buried as soon as possible, an Islamic requirement. Are these reasons justified?
\end{abstract}

Islamic law is derived from three sources: the Koran, the Sunnah-which includes the teachings, whether by word or deed, of Mohammed-and ijtihad, the process of deductive logic. The laws set by the Koran and Sunnah are obligatory for all Muslims and cannot be disputed. Ijtihad opinion is formulated by a single scholar or group of scholars who reach a consensus. The ruling, called a fatwa, is not binding. It can be right or wrong and can be debated and modified, so a range of views on a given question is possible.

Although most Muslims believe that Islam doesn't allow autopsies, neither the Koran nor the Sunnah has actually addressed the issue. The belief is based only on the ijtihad of scholars and on cultural beliefs wrongly attributed to Islam. Muslims used to believe that organ transplantation was not permitted in Islam. In 1952 the supreme head of the Islamic School of Jurisprudence in Egypt issued a fatwa that if anything was of "good" for humanity then "necessity allows what is prohibited" (BMJ 1994;309:521-3). The ruling allowed organ transplantation in certain circumstances, and now many Muslims see organ donation as a charitable act. In Britain a collaborative effort led to a fatwa allowing Muslims to donate organs and carry donor cards.

Building on the 1952 ruling, a fatwa committee in 1982 found that the benefits of autopsies outweighed the drawbacks if they increase the knowledge of medical students and doctors, help control contagious diseases, and serve the cause of

We welcome submissions for the personal view section. These should be no more than 850 words and should be sent electronically via our website. For information on how to submit a personal view online, see http://bmj.com/cgi/content/full/325/ 7360/DC1/1 justice. The main reason for hospital autopsies is to help the family understand what went wrong and in perinatal cases to identify problems that can be avoided in future pregnancies. Also, autopsies benefit medical science, so there is no reason why they cannot be permitted.

The belief among Muslims that autopsies are unnecessary because everything, including death, happens according to God's will is illogical. Illness also happens through God's will, and no Muslim would argue against treating sick people. The guiding principles of Islamic law include the maintenance of life and of the intellect. The first verse of the Koran revealed to Mohammed commanded him to read (to learn), and countless teachings of the Prophet encourage Muslims to learn and apply their knowledge for the benefit of all. Autopsies are essential to increase our understanding of disease processes, to determine accuracy of clinical diagnoses, and to assess effectiveness of treatments. Although death is God's will there is no reason why we cannot do autopsies, learn from them, and apply our knowledge for the benefit of all.

With advances in diagnostic tests and imaging techniques, clinical diagnoses have become increasingly accurate. This has resulted in a perceived decline in the value of the autopsy among doctors and the public. Yet studies have shown that new information was gathered in a quarter of autopsies (BMJ 2002;324:761-3). Perinatal mortality among Pakistani mothers in Britain is twice the national average, indicating a need to investigate underlying causes in this group. Furthermore, irrespective of medical advances, the autopsy remains valuable in the counselling of families after the loss of an infant, as it can help in the grieving process, improve parents' understanding, and alleviate concerns.

Islam forbids the disfigurement or desecration of dead bodies. This has been taken literally by many Muslims as pertaining to autopsies. But Mohammed said that deeds depend on the intentions behind them. As the intention behind autopsies is the benefit to the family, medical science, and society, and if they are carried out according to the law of the land and pathologists' guidelines, then they should be regarded not as desecration but another medical procedure. An empathetic explanation to the family about an autopsy's purpose and that the body is treated with great respect would allay many concerns. Family wishes, such as not examining the

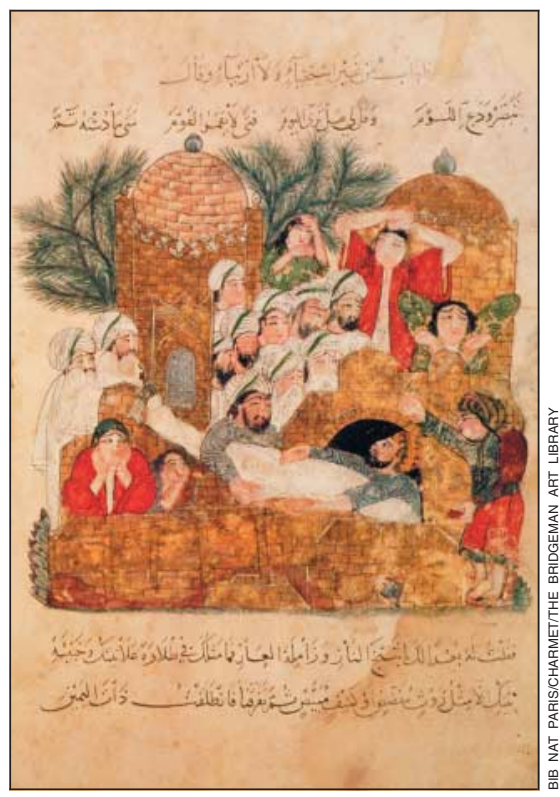

Body politics: autopsies need not delay burial

head and returning all tissues back to the body, can also be accommodated.

With respect to burying the body, this should be done as soon as practically possible. Many Muslim families send their loved ones back to their original countries for burial, a process that can take up to a week. If pathologists are informed that the dead person is a Muslim they should be happy to do the autopsy as soon as possible. This is the current practice at the Royal London Hospital.

So what can we do to improve the rate of autopsies, including perinatal and paediatric autopsies, in the Muslim population? The "three Cs" of Toronto Hospital for Sick Children's paediatric autopsy service are relevant: communication (by experienced professionals who have some knowledge of the religious and cultural beliefs of Muslims and can explain to families the procedure and potential benefits of autopsies), compassion (showing families that their concerns are understood), and compliance (changing the protocol and timing of the autopsy as needed and if possible).

Most religious objections to autopsy derive not from the principles of the faith but from personal interpretations and anxiety. Most can be alleviated by knowledge, understanding, and respect.

Mudher Al-Adnani specialist registrar madnani8@hotmail.com

Irene Scheimberg consultant paediatric pathologist, Department of Histopathology, Institute of Pathology, The Royal London Hospital, London 


\section{Lessons for doctors from Jewish philosophy}

I

became active in the Jewish community and interested in medicine at about the same time. I was in high school, and I became involved in my synagogue's youth group. I loved the friends I made and the programmes I attended. And although there were no formal educational sessions, over time I learnt by example the values of social activism, leadership, community, personal growth, and ethical development.

In the same year that I became president of my youth group I met Dr Ipp. I used to run Dr Ipp's office when he was working on call on the weekends. One Saturday he took me to a movie after work. Just before Hamlet's major monologue he was paged. A woman's baby had fallen and lost consciousness for a moment. Dr Ipp insisted that she take the baby to the hospital, but the woman refused, saying that she didn't want to drive on the Sabbath. Although in Judaism the saving of a life takes precedence over the customs of Shabbat, the woman continued to refuse. "Come on," Dr Ipp said to me, "it's not a child's fault who his parents are. We'll have to go see the baby." There were times when Dr Ipp picked a medical issue and taught me how it would present and how it was managed. But more often, in his actions and in his dealings with people, he would remind me, "Being a doctor is about more than the physical exam. It's about looking at television and asking if it is harmful or looking at education and asking if it is sufficient, based on the knowledge of what makes a child healthy."

When I came to university, on alternate weeks I wanted to be a rabbi or a doctor. I ultimately decided that I didn't need to be a rabbi to be a Jewish leader. And I felt that pursuing medicine would be a similar path to becoming a rabbi, as the way Dr Ipp practised medicine made the differences between being a rabbi and being a doctor seem trivial. Both professions pursue justice and wellbeing for vulnerable people; both are devoted to working in partnership with people in the community to bring about healing, personal growth, and responsible societies.

Now, coming to the close of my first year at medical school, I have found myself reflecting on the lack of such guidance. Most of my time has been taken up in uninspiring lectures and in reading copious notes. I used to be passionate. I used to debate issues and find books or articles about the things that made me excited. I used to read about poverty, the health of young Canadian aboriginals, and community programmes for children at risk. Now I never think critically. Every day I read, highlight, and reread the notes I have been given, so that I can choose the right answers in multiple choice examinations. Even in small group sessions I often feel I am being trained to minister basic science to anthropomorphised diseases. I feel emotionally stagnant and creatively stunted. I expected the first year of school to be difficult. I didn't imagine I would be sitting here, almost at the end, writing an essay about being farther from healing and medicine than ever before in my life and worried that in pursuing the study of humanity I would lose my own.

At the same time, one of my friends completed her first year of rabbinical school. Her first year of professional training has also been challenging, but for her the challenge comes from her teachers, who are concerned with her development as a person and constantly push her to grow. She said, "Partly it's because they want us to experience a rich spiritual life. Also, we'll constantly be struggling with difficult questions, so they want us to have a framework within which to understand ourselves and our reactions. Being a religious leader isn't just about having all the knowledge-it's about how you relate to what you know and how you can help others relate to what you know."

The personal and spiritual development of doctors is no less important than that of rabbis. Doctors need to be whole people if they are to help their patients be whole people. Patients, like congregants, expect their doctors to know everything-and most of those things have not been made available for Palm Pilots. Medicine means more than caring people practising basic science.

If I were in rabbinical school I would be learning for life-being a Jewish leader is not a day job. It is not about being at the bedside between 9 am and $5 \mathrm{pm}$; it is about sitting with ill people when they cannot stand. It is a way of life and it is a set of beliefs-not just in God, but in community, in the value of leadership and role modelling, and in responsibility to young people. In this way medical education has a great deal to learn from Jewish philosophy. Young medical students cannot become healers if a focus on their emotional and spiritual development is confined to a limited lecture series. They will not take an interest in their patients as people if their mentors do not take an interest in developing students as people. They will not learn to think critically or to approach life creatively if the spiritual dimensions of illness are not considered. Personal growth and spirituality are not just issues for our patients.

Naomi Lear medical student, McGill University, Canada

Naomi.Lear@mail.mcgill.ca

\section{SOUNDINGS}

\section{Failure to die}

A long time ago, as a locum senior house officer, I followed the senior consultant round the ward. One of his patients, a frail, eccentric woman in the last stages of dementia, had a serious chest infection. He frowned and pondered, warned us off antibiotics, said he would talk to the family, and told us that our remaining duties were to ensure "comfort, dignity, and peace at the last."

The next time we went round our patient was looking very well indeed and enjoying her porridge, but the chief was not in the least put out. He exchanged his usual courtesies with her and then asked for her temperature chart. I was treated to some bedside teaching on "crisis and lysis": the remorseless advance of a fever and its sudden precipitous fall, with the latter as something that once, in the pre-antibiotic era in which he had trained, could only be hoped and prayed for.

Failure to thrive, I learnt as a student, was one of the more testing

presentations in paediatrics. At the other end of life and in the context of presumed mortal illness, its corollary-failure to die-also gives rise to some puzzlement, little of which we acknowledge.

The prognosis involved is a dubious science; even hospice doctors get the occasional surprise. And perhaps it is also something to do with the might of modern medicine: if we have decided that despite it all there's no hope, or that you are so near the end you are just not entitled, then it is clearly unsettling to the general order of things when you come back, as that woman did 30 years ago, for more porridge.

I see the presentation from time to time, and still find it intriguing. Families are rarely surprised ("She's always had a strong heart, doctor"). Nurses are usually quite pleased, because in most cases such survival reflects their skill and art. But others find it difficult: most commonly the junior hospital doctors, and particularly the most presumptuous of them-those who never envisaged the need for a plan B.

So what should we teach them? Life is uncertain and so is death, so why not be a bit more relaxed about this? And what they have to learn is simple but quite important, though not easy to define and not much prized among students and trainees. Saying you're not sure? Not minding being wrong? Humility, perhaps?

Colin Douglas doctor and novelist, Edinburgh 